\title{
ANALISIS KOMPARATIF KINERJA KEUANGAN BANK UMUM SYARIAH PADA MASA PANDEMI COVID-19
}

\author{
Putri Diesy Fitriani \\ UIN Sunan Gunung Djati Bandung \\ putridiesy@uinsgd.ac.id
}

\begin{abstract}
ABSTRAK
Penelitian ini bertujuan untuk membandingkan serta melihat perbedaan antara kinerja keuangan Bank BRI Syariah dengan Bank BNI Syariah pada rasio Non Performing Financing (NPF), Return On Assets (ROA), Biaya Operas.ional terhadap Pendapatan Operasional (BOPO) dan Financing to Deposit Ratio (FDR). Metode yang digunakan dalam penelitian ini adalah metode penelitian komparatif dengan analisis data kuantitatif dengan menggunakan uji beda dua rata-rata. Hasil penelitian ini menyatakan bahwa terdapat perbedaan yang signifikan pada kinerja keuangan BRI Syariah dengan BNI Syariah dalam rasio NPF, ROA dan BOPO dengan nilai signifikansi 0,000<0,05. Sedangkan pada rasio FDR tidak terdapat perbedaan yang signifikan antara Bank BRI Syariah dengan Bank BNI Syariah dengan nilai signifikansi 0,429>0,05.
\end{abstract}

\section{Kata Kunci : NPF, ROA, BOPO, FDR}

\begin{abstract}
This study aims to compare and see the differences between the financial performance of BRI Syariah Bank and BNI Syariah Bank in the ratio of Non Performing Financing (NPF), Return On Assets (ROA), Operational Costs to Operating Revenue (BOPO) and Financing to Deposit Ratio ( FDR). The method used in this study is a comparative research method with quantitative data analysis using Two Sample T-Test. The results of this study indicate that there are significant differences in the financial of BRI Syariah with BNI Syariah in the ratio of NPF, ROA and BOPO with a significance value of $0,000<0.05$. While in the FDR ratio there is no significant difference between BRI Syariah Bank and BNI Syariah Bank with a significance value of 0.429>0.05.
\end{abstract}

Key Word : NPF, ROA, BOPO, FDR 


\section{PENDAHULUAN}

Perekonomian global saat ini mendapatkan pukulan yang sangat keras. Hal ini disebabkan karena terjadinya pandemi yang terjadi di hampir seluruh negara di dunia termasuk Indonesia. Corona virus desease 2019 (Covid-19) merupkan coronavirus baru yang mana dahulu kelompok virus ini hanya ditemukan pada hewan. Terjadinya Covid-19 diawali berdasarkan info dari World Health Organization (WHO) yang mengatakan bahwa pada 31 Desember terdapat kasus pneumonia dengan etiologi baru di Wuhan provisnis Hubei, China. ${ }^{1}$

Penyebaran Covid-19 sangatlah cepat hingga ke seluruh penjuru dunia, termasuk negara-negara maju termasuk USA, Inggris, Korea Selatan tak terkecuali Indonesia. Covid-19 merupakan ancaman yang serius bukan hanya bagi kesehatan manusia namun juga perkonomian bangsa, selain korban jiwa yang sudah banyak dikarenakan virus tersebut tingkat kemiskinan pun diperkirakan meningkat signifikan. Institute for Demographic and Property Studies (IDEAS) menyatakan bahwa prediksi kemiskinan di Indonesia yang disebabkan pandemi ini akan mencapai 15\% yang pada mulanya hanya $9,22 \% .^{2}$

Sektor bisnis di Indonesia pun turut mendapatkan dampak negative akan terjadinya pandemic yang terjadi. Kinerja

${ }^{1}$ Editor, Materi Komunikasi Risiko Covid-19 untuk Fasilitas Pelayanan Kesehatan. (https://www/who.int/ docs/default-source/searo/9/indonesia/covid19/riskcommunication-for-healthcare-facility.pdf?sfvrsn= 9207787a 2 diakses pada tanggal 2 Maret 2020). perusahaan yang bergerak dibidang property, pariwisata, manufaktur, otomotif, keuangan bahkan UMKM sekalipun. Di balik kemerosotannya sektor keuangan, masih terdapat salah satu sektor yang masih memiliki kinerja yang stabil jika dibandingkan dengan sektor lain yaitu Perbankan Syariah.

Bank merupakan Departement of Store, yang bermakna suatu lembaga jasa dengan berbagai pelayanan jasa keuangan. Bank memiliki tiga kegiatan utama, di antaranya: Pertama, simpanan dana dari masyarakat berupa giro, tabungan dan deposito. Kedua, memberikan pembiayaan bagi masyarakat yang membutuhkan. Ketiga, melayani berbagai jenis layanan pembayaran atau setoran. ${ }^{3}$

Perbankan syariah mampu tumbuh dengan baik walaupun berada dalam situasi pandemic Covid-19. Perbankan syariah cenderung memiliki risko yang relative kecil saat pandemic dikarenakan konsep syariah yang berkeadilan, transparansi dan kemaslahatan yang secara tidak langsung memitigasi akibat yang timbul dari pandemi Covid-19. Tumbuh dengan baik suatu perbankan syariah dapat dilihat dari kinerja kuangan perbankan syariah itu sendiri.

Kinerja keuangan bank syariah merupakan suatu gambaran mengenai kondisi keuangan bank syariah pada suatu

\footnotetext{
2 Siti Yona Hukmana, Angka Kemiskinan Diprediksi Naik 15\% Akibat Covid-19. Retrieved Juni 16, 2020 https://www.medcom.id/nasional/peristiwa/ybDIAyXb -angka-kemiskinan-diprediksi-naik-15-akibat-covid-19 Diakses pada tanggal 16 Juni 2020).

3 Kasmir, Bank dan Lembaga Keuangan Lainnya, (Jakarta: Raja Grafindo, 2008) hlm. 25
} 
periode tertentu, baik perbulan, triwulan atau tahunan yang mencakup aspek penghimpunan dan penyaluran dana bank syariah itu sendiri. ${ }^{4}$ Penilaian kinerja keuangan bank syariah itu sendiri dapat dilakukan dengan menggunakan analisis terhadap laporan keuangan bank syariah yang bersangkutan. Kinerja keuangan bank syariah berbanding lurus dengan tingkat kesehatannya. Hal tersebut menandakan bahwa semakin baik kinerja keuangan bank syariah maka semakin baik juuga tingkat kesehatan bank syariah itu sendiri begitupun sebaliknya. Kinerja keuangan bank syariah dapat diukur dengan menggunakan rasio keuangan tertentu.

BRI Syariah merupakan satu-satunya perbankan syariah yang sudah mencatatkan sahamnya di Bursa Efek Indonesia sejak 9 mei 2018 dengan Kode saham BRIS. Perjalanan BRI Syariah yang cukup panjang sejak tahun 2008 menjadi prestasi yang sangat baik jika dibandingkan dengan perbankan syariah lainnya yang belum terdaftar di BEI. ${ }^{5}$

Berdasarkan laporan keuangan publikasi BRI Syariah, sejak masa pandemi covid 19 di wuhan China pada Desember 2019 hingga sampai di Indonesia Maret 2020 belum memiliki dampak yang besar bagi nasabah maupun BRI Syariah itu

${ }^{4}$ Putu Widhi Iswari, Amanah. Kinerja Keuangan Bank Umum Syariah: Negara vs Swasta. Islaminomic, 6(2) 2015. hlm 1-15

${ }^{5}$ Editor, Profil Perusahaan PT Bank BRI Syariah, ((https://www.brisyariah.co.id/company_profile.php?i $\mathrm{dp}=7688$ ee5e1952646f4bdbeb5a489cd596 Diakses pada 11 November 2018)

6 Lukman Dendawijaya, Manajemen Perbankan, (Jakarta: Ghalia Indonesia, 2009) hlm. 82

7 Return On Asset (ROA) adalah rasio yang menunjukkan seberapa besar kontribusi aset dalam sendiri, dilihat dari presentasi pembiayaan bermasalah yang justru menurun dari $3,38 \%$ menjadi $2,95 \%$ pada triwulan pertama 2020. Pembiayaan bermasalah itu sendiri adalah kegagalan membayar kewajiban atas pembiayaan yang diterima oleh nasabah pada saat jatuh tempo. ${ }^{6}$ Selain itu kemampuan dalam menghasilkan laba dari rasio $\mathrm{ROA}^{7}$ pun meningkat pesat menjadi $1 \%$. Hal ini menandakan bahwa BRI Syariah selain memiliki kemampuan bertahan yang bagus dalam masa pandemic Covid-19 juga memiliki kemampuan untuk meningkatkan kinerja dengan baik. ${ }^{8}$

Selain BRI Syariah, BNI Syariah pun dinilai memiliki prestasi yang cukup baik berdasarkan kinerja keuangan. Dari periode ke periode tingkat pembiayaan bermaslaah di BNI Syariah relative stabil tidak pernah melebihi 1,8\%. Walaupun memang sejak awal mula masa pandemic di Indonesia tingkat pembiayaan bermasalah yang dinyatakan dalam rasio $\mathrm{NPF}^{9}$ mengalami peningkatan, di sisi lain BNI Syariah juga mengalami peningkatan pada rasio ROA dan mengalami penurunan dalam

menciptakan laba bersih. Hery. Analisis Laporan Keuangan. (Yogyakarta: CAPS, 2015). hlm. 228

${ }^{8}$ Editor, Laporan Keuangan Publikasi BRI Syariah (https://www.ojk.go.id/id/kanal/perbankan/data-danstatistik/laporan-keuangan-perbankan/default.aspx diakses 10 Juni 2020)

${ }^{9}$ Non Performing Financing (NPF) adalah rasio pembiayaan bermasalah bank syariah dengan rumus total pembiayaan dibagi total pembiayaan yang dinyatakan dalam persentase. Muhammad, Manajemen Bank Syariah, (Yoogyakarta: UUP AMPY KPN, 2005) hlm. 265 
rasio $\mathrm{BOPO}^{10}$ dan $\mathrm{FDR}^{11}$ pada periode yang sama. $^{12}$

Berdasarkan pemaparan latar belakang diatas maka rumusan masalah dalam penetian ini adalah apakah terdapat perbedaan kinerja keuangan BRI Syariah dengan BNI Syariah pada masa pandemic Covid-19.

Adapun metode yang digunakan dalam penelitian ini adalah metode penelitian komparatif, dimana penelitian ini bersifat membandingkan variabel yang sama yang sifatnya membandingkan persamaan dan perbedaan dua atau lebih sifat-sifat dan fakta-fakta objek yang diteliti berdasarkan suatu kerangka pemikiran tertentu. ${ }^{13}$ variabel yang digunakan dalam penelitian ini yaitu Non Performing Financing (NPF), Return On Assets (ROA), Beban Operasionak terhadap Pendapatan Operasional (BOPO) dan Financing to Deposit Ratio (FDR). Analisis yang digunakan adalah analisis uji beda dengan dua rata-rata dengan menggunakan minitab software. data yang digunakan dalam penelitian ini yaitu data sekunder yang merupakan laporan keuangan publikasi Bank BRI Syariah dan BNI Syariah dalam situs resmi Otoritas Jasa Keuangan (OJK) periode 2019 sampai dengan awal mula terjadinya pandemi covid -19 tahun 2020 .

\section{PEMBAHASAN}

Analisis komparasi yang dilakukan dalam penelitian ini dimulai dengan menghitung rasio keuangan diantaranya rasio non performing financing (NPF), return on assets (ROA), beban operasional terhadap pendapatan operasional (BOPO) dan financing to deposit ratio (FDR) kemudian di analisis menggunakan analisis uji beda dua rata-rata menggunakan minitab software. Selanjutnya akan diketahui siginifikan atau tidaknya perbedaan antara kinerja keuangan Bank BRI Syariah dengan Bank BNI Syariah 2019 - Pertengahan 2020. Berikut merupakan hasil perhitungan dalam penelitian ini:

Perbedaan kinerja keuangan pada non performing financing antara Bank BRI Syariah dengan Bank BNI Syariah.
10 BOPO adalah rasio yang digunakan untuk mengukur efisiensi dan kemampuan manajemen bank dalam mengendalikan operasinya. Rivai Veithrizal dan Rifki Ismail, Islamic Risk Management For Islamic Bank, (Jakarta: Gramedia Pustaka Utama, 2013) hlm 131.

11 Financing to Deposit Ratio (FDR) adalah merupakan perbandingan antara pembiayaan yang diberikan oleh bank dengan pihak ketiga yang berhasil diusahakan oleh bank. Muhammad, hlm. 260

12 Editor, Laporan Keuangan Publikasi BNI Syariah (https://www.ojk.go.id/id/kanal/perbankan/data-danstatistik/laporan-keuangan-perbankan/default.aspx diakses 10 Juni 2020)

13 Sugiyono, Metode Penelitian Kuantitatif, Kualitatif dan $R \&$ D. (Bandung: Alfabeta, 2011) hlm. 11 
Two-Sample T-Test and CI: BRIS, BNIS

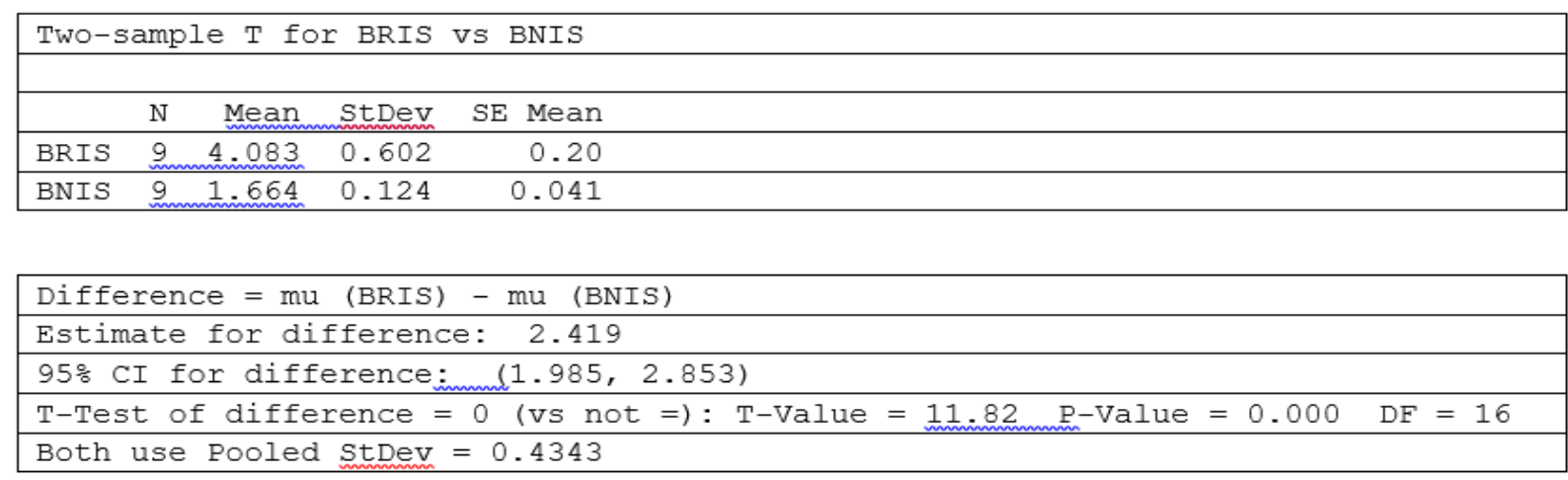

Gambar 1

Perbedaan Kinerja Keuangan pada non performing financing (NPF) BRI Syariah dengan BNI Syariah

Berdasarkan data di atas dapat diketahui bahwa rasio non performing financing (NPF) BRI Syariah adalah sebesar 4,083\% sedangkan rata-rata non performing financing (NPF) BNI Syariah adalah sebesar 1,664\%. Berdasarkan hasil uji beda dua rata-rata diperoleh nilai signifikansi sebesar $0.000<0.05$. dengan demikian dapat dirumuskan bahwa terdapat perbedaan yang signifikaan antara kinerja keuangan BRI Syariah dengan BNI Syariah pada rasio non performing financing (NPF). Kinerja keuangan BNI Syariah pada rasio non performing financing (NPF) memiliki kinerja yang lebih baik dikarenakan memiliki nilai rata-rata yang lebih kecil jika dibandingkan dengan BRI Syariah. Jika merujuk pada kriteria NPF menurut Surat Edaran Bank Indonesia No.92/24.DPbs tahun 2007 kondisi BNI Syariah dapat dikatakan dalam kategori Sangat Sehat sedangkan BRI Syariah dapat dikategorikan Sehat. Berikut Tabel kriteria kesehatan bank pada rasio non performing financing (NPF): ${ }^{14}$

Tabel 1

Kriteria NPF

\begin{tabular}{|c|c|c|}
\hline Rasio & Peringkat & Penilaian \\
\hline $\mathrm{NPF}<2 \%$ & 1 & Sangat Sehat \\
\hline $2 \% \leq \mathrm{NPF}<5 \%$ & 2 & Sehat \\
\hline $5 \% \leq \mathrm{NPF}<8 \%$ & 3 & Cukup Sehat \\
\hline $8 \% \leq \mathrm{NPF}<12 \%$ & 4 & Kurang Sehat \\
\hline $\mathrm{NPF} \geq 12 \%$ & 5 & Tidak Sehat \\
\hline
\end{tabular}

Sumber : Surat Edaran Bank Indonesia No.92/24.DPbs tahun 2007

14 Surat Edaran Bank Indonesia No.9/24/DPbS tahun 2007 tentang Sistem Penilaian Tingkat Kesehatan Bank Umum Berdasarkan Prinsip Syariah 
1. Perbedaan Kinerja Keuangan pada Return On Assets (ROA) antara BRI Syariah dengan BNI Syariah

\begin{tabular}{|lrrrr|}
\hline \multicolumn{7}{|c|}{ Two-sample T for BRIS VS BNIS } \\
\hline \multicolumn{7}{|c|}{ N } & Mean & StDev & SE Mean \\
\hline BRIS & 9 & 0.596 & 0.287 & 0.096 \\
\hline BNIS & 9 & 1.690 & 0.313 & 0.10 \\
\hline
\end{tabular}

\begin{tabular}{|l}
\hline Difference $=\mathrm{mu}$ (BRIS) $-\mathrm{mu}$ (BNIS) \\
\hline Estimate for difference: -1.094 \\
\hline 95\% CI for difference: $(-1.394,-0.795)$ \\
\hline T-Test of difference $=0$ (vs not $=$ ) : T-Value $=-7.74 \quad$ P-Value $=0.000 \quad$ DF $=16$ \\
\hline Both use Pooled StDev $=0.2999$
\end{tabular}

Gambar 2

Perbedaan Kinerja Keuangan pada Return On Assets (ROA) BRI Syariah dan BNI Syariah

Berdasarkan data di atas dapat diketahui bahwa rata-rata return on assert (ROA) pada BRI Syariah adalah 0.596\% sedangkan rata-rata retun on assets (ROA) BNI Syariah adalah sebesar 1,690. Selanjutnya hasil uji beda dua rata-rata diperoleh p value sebesar 0,000 oleh karena itu nilai signifikansinya $0,000<0,05$. Dengan demikian dapat dirumuskan bahwa terdapat perbedaan yang signifikan anntara kinerja keuangan BRI Syariah dengan BNI Syariah pada rasio return on assets (ROA).
Hasil penelitian menunjukan bahwa kinerja keuangan BNI Syariah jauh lebih baik jika dibandingkan dengan kinerja keuangan BRI Syariah pada rasio return on assets (ROA) dikarenakan memiliki nilai mean yang lebih tinggi, disesuaikan dengan tingkat kesehatan bank dengan kriteria return on assets (ROA) BNI Syariah masuk kategori Sangat Sehat sedangkan BRI Syariah dapat dikategorikan Cukup Sehat. ${ }^{15}$ Berikut tabel kriteria return on assets (ROA) menurut Bank Indonesia :

Tabel 2

Kriteria Return On Assets (ROA)

\begin{tabular}{|c|c|c|}
\hline Rasio & Peringkat & Penilaian \\
\hline ROA $.1,5 \%$ & 1 & Sangat Sehat \\
\hline $1,25 \%<$ ROA $\leq 1,5 \%$ & 2 & Sehat \\
\hline $0,5 \%<$ ROA $\leq$ & 3 & Kurang Sehat \\
$1,25 \%$ & 4 & Tidak Sehat \\
\hline $0<$ ROA $\leq 0,5 \%$ & 5 & \\
\hline ROA $\leq 0 \%$ & & \\
\hline
\end{tabular}

15 Surat Edaran Bank Indonesia No.9/24/DPbS tahun 2007 tentang Sistem Penilaian Tingkat Kesehatan Bank Umum Berdasarkan Prinsip Syariah 
putri diesy fitriani

Sumber : Surat Edaran Bank Indonesia No.92/24.DPbs tahun 2007 
Perbedaan Kinerja Keuangan pada Beban Operasionan terhadap Pendapatan Operasional (BOPO) antara BRI Syariah dengan BNI Syariah

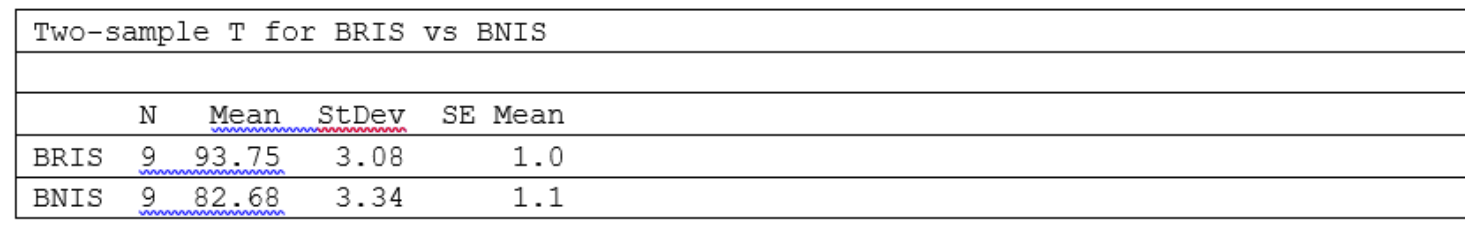

\begin{tabular}{|l|}
\hline Difference $=\mathrm{mu}$ (BRIS) $-\mathrm{mu}$ (BNIS) \\
\hline Estimate for difference: 11.07 \\
\hline 95\% CI for difference: $:(7.86,14.28)$ \\
\hline T-Test of difference $=0$ (vs not $=$ ) : T-Value $=7.31$ P-Value $=0.000 \quad$ DF $=16$ \\
\hline Both use Pooled StDev $=3.2132$ \\
\hline
\end{tabular}

Gambar 3

Perbedaan Kinerja Keuangan pada BOPO BRI Syariah dan BNI Syariah

Berdasarkan data yang telah dijelaskan di atas, dapat diketahui bahwa ratarata BOPO dari BRI Syariah adalah sebesar 93,75\%. Sedangkan BNI Syariah memiliki nilai BOPO dengan rata-rata sebesar $82,68 \%$. Berdasarkan hasil analisis uji beda dua rata-rata diperoleh nilai $\mathrm{p}$ value sebesar 0,000 dengan demkian hasil signifikansinya sebesar 0,000, 0,05 hal tersebut menandakan bahwa terdapat perbedaan yang signifikan antara kinerja keuangan BRI Syariah dengan kinerja keuangan BNI Syaraiah pada rasio BOPO.

Hasil tersebut juga menjelaskan bahwa jika dilihat dari rasio $\mathrm{BOPO}$, kinerja keuangan BNI Syariah lebih baik jika dibandingkan dengan BOPO pada BRI Syariah, hal ini dilihat dari nilai rata-rata BOPO BNI Syariah lebih kecil jika dibandingkan dengan nilai BOPO pada BRI Syariah. Semakin kecil nilai BOPO bank syariah, maka akan semakin efektif kinerja keuagan bank syariah itu sendiri. ${ }^{16}$ Namun jika dilihat dari hasil nilai rata-rata rasio BOPO yang dimiliki oleh BRI Syariah dan BNI Syariah kedua bank umum syariah tersebut masuk dalam kriteria sangat sehat. ${ }^{17}$ Berikut tabel kriteria rasio $\mathrm{BOPO}$ menurut Bank Indonesia :
16 Dendawijaya, Lukman. (2009). Manajemen Perbankan. Jakarta: Ghalia Indonesia.
17 Surat Edaran Bank Indonesia No. 6/23/DPNP Tahun 2004

Volume II/ Nomor 02/ Juli 2020 
Tabel 3

Kriteria BOPO

\begin{tabular}{|c|c|c|}
\hline Rasio & Peringkat & Penilaian \\
\hline BOPO $\leq 94 \%$ & 1 & Sangat Sehat \\
\hline $\begin{array}{c}94 \%<\mathrm{BOPO} \leq \\
95 \%\end{array}$ & 2 & Sehat \\
\hline $\begin{array}{c}95 \%<\mathrm{BOPO} \leq \\
96 \%\end{array}$ & 3 & Cukup Sehat \\
\hline $\begin{array}{c}96<\mathrm{BOPO} \leq \\
97 \%\end{array}$ & 4 & Kurang Sehat \\
\hline BOPO $>97 \%$ & 5 & Tidak Sehat \\
\hline
\end{tabular}

Sumber : SE BI No. 6/23/DPNP Tahun 2004

2. Perbedaan kinerja keuangan pada Financing to Deposit Ratio (FDR) antara BRI Syariah dengan BNI Syariah.

\begin{tabular}{|lrrrr|}
\hline \multicolumn{1}{|l|}{ Two-sample T for BRIS VS BNIS } \\
\hline \multicolumn{7}{|c|}{ N } & Mean & StDev & SE Mean \\
\hline BRIS & 9 & 90.64 & 7.45 & 2.5 \\
\hline BNIS & 9 & 78.17 & 5.29 & 1.8 \\
\hline
\end{tabular}

\begin{tabular}{|l|}
\hline Difference $=\mathrm{mu}$ (BRIS) $-\mathrm{mu}$ (BNIS) \\
\hline Estimate for difference: 2.47 \\
\hline 95\% CI for difference: $(-3.98,8.93)$ \\
\hline T-Test of difference $=0$ (vs not $=$ ) : T-Value $=0.81$ P-Value $=0.429 \quad$ DF $=16$ \\
\hline Both use Pooled StDev $=6.4627$ \\
\hline
\end{tabular}

Gambar 4

Perbedaan Kinerja Keuangan pada Financing to Deposit Ratio (FDR) BRI Syariah dengan BNI Syariah

Berdasarkan data di atas, dapat diketahui bahwa rata rata Financing to Deposit Ratio (FDR) BRI Syariah adalah sebesar 80,64\%. Sedangkan rata-rata Financing to Deposit Ratio (FDR) BNI Syariah adalah sebesar 78,17\%. Setalah dianalisi menggunakan analisis uji beda dua rata-rata dengan nilai $p$ value sebesar 0,429 , sehingga nilai signifikansinya sebesar 0,429 >
0,05. Dengan demikian dapat dirumuskan bawa tidak terdapat perbedaan yang signifikan antara Financing to Deposit Ratio BRI Syariah dngan BNI Syariah. Perbedaan diantara kedua Bank Syariah tersebut tidak terpaut jauh hanya sebesar 2,47\%. Hasil rata-rata nilai Financing to Deposit Ratio (FDR) kedua Bank Syariah tersebut masuk dalam kriteria Sehat. ${ }^{18}$ Berikut tabel 
penentuan kriteria kesehatan bank pada

Financing to Deposit Ratio (FDR) :

Tabel 4

Kriteria FDR

\begin{tabular}{|c|c|c|}
\hline Rasio & Peringkat & Penilaian \\
\hline FDR $\leq 75 \%$ & 1 & Sangat Sehat \\
\hline $\begin{array}{c}75 \%<\text { FDR } \leq \\
85 \%\end{array}$ & 2 & Sehat \\
\hline $\begin{array}{c}85 \%<\text { FDR } \leq \\
100 \%\end{array}$ & 3 & Cukup Sehat \\
\hline $\begin{array}{c}100<\text { FDR } \leq \\
120 \%\end{array}$ & 4 & Kurang Sehat \\
\hline FDR $>120 \%$ & & Tidak Sehat \\
\hline
\end{tabular}

Sumber : SE BI No. 6/23/DPNP Tahun 2004

\section{SIMPULAN}

Berdasarkan pada hasil analasis data yang suduah dijelaskan, maka penulis dapay mengambil beberapa kesimpulan :

Terdapat perbedaan secara signifikan kinerja keuangan pada rasio Non Performing Financing (NPF) antara BRI Syariah dengan BNI Syariah. Hal tersebut dapat diketahui berdasarkan perhitungan menggunakan minitab software diperoleh nilai signifikansi sebesar 0,000>0,05

Terdapat perbedaan secara signifikan kinerja keuangan pada rasio Return On Asset (ROA) antara BRI Syariah dengan BNI Syariah. Hal tersebut diketahui berdasarkan perhitungan menggunakan mintab software diperoleh nilai signifikanis sebesar $0,000<0,05$.
Terdapat perbedaan yang signifikan dalam kinerja keuangan pada rasio BOPO antara BRI Syariah dengan BNI Syariah. Hal tersebut dapat diketahui beradasarkan penghitungan menggunakan mintab software dan diperoleh nilai signifikansinya sebesar $0,000<0,05$.

Tidak terdapat perbedaan yang signifikan dalam kinerja keuangan pada Financing to Deposit Ratio (FDR) anatar BRI Syariah dengan BNI Syariah. Hal tersebut dapat diketahui dari hasil penghitungan menggunakan minitab software dan diperoleh nilai signifikansinya sebesar 0,429 > 0,05 . 


\section{DAFTAR PUSTAKA}

Bank BRI Syariah, Profil Perusahaan PT Bank BRI Syariah, (www.brisyariah.co.id) diakses pada 11 November 2018

Dendawijaya, L. (2009). Manajemen Perbankan. Jakarta: Ghalia Indonesia.

Hery. (2015). Analisis Laporan Keuangan. Yogyakarta: CAPS.

Hukmana, S. Y. (2020, Juni 16). Angka Kemiskinan Diprediksi Naik 15\% Akibat Covid19.

Kasmir. (2008). Bank dan Lembaga Keuangan Lainnya. Jakrta: Raja Grafindo.

Muhammad. (2005). Manajemen Bank Syariah. Yogyakarta: UUP AMPY KPN.

Otoritas Jasa Keuangan, Laporan Publikasi Bank BRI Syariah. Online (www.ojk.go.id) diakses 10 Juni 2020

Otoritas Jasa Keuangan, Laporan Publikasi Bank BNI Syariah. Online (www.ojk.go.id) diakses 10 Juni 2020

Putu Widhi Iswari, A. (2015). Kinerja Keuangan Bank Umum Syariah: Negara vs Swasta. Islaminomics, 1-15.

Rivai Veithrizal, Rifki Ismail. (2013). Islamic Risk Management For Islamic Bank. Jakarta: Gramedia Pustaka Utama.

Sugiono, Metodologi Penelitian Kuantitatif, Kualitatif dan R \& D. Bandung: Alfabeta

Surat Edaran Bank Indonesia No. 9/24/DPbs tahun 2007 tentang Sistem Penilaian Tingkat Kesehatan Bank Umum Berdasarkan Prinsip Syariah

Surat Edaran Bank Indonesia No. 6/23/DPNP Tahun 2004 tentang Sistem Penilaian Tingkat Kesehatan Bank Umum dan lampiran

World Health Organization Indonesia, Materi Komunikasi Risko Covid-19 untuk Fasilitas Pelayanan Kesehatan. Online (www.who.int/Indonesia) diakses pada 2 Maret 2020 
putri diesy fitriani 